Rebecca Boehling

\title{
From Tracing and Fate Clarification to Research Center
}

\author{
The Role of International Players and Transnationalism in \\ Shaping the Identity of the ITS
}

\begin{abstract}
The more international influence there was on and within the ITS, the more likely the ITS and its staff were to manifest and reflect a transnational culture of memory of and for an increasingly broadly defined group of victims. This was true early on due to its very international staff; however, with growing Cold War constraints and priorities and an increasing reliance on regional German staff under International Committee of the Red Cross (ICRC) management, the identity and volume of those served by the ITS narrowed. Only as a result of renewed international pressure following the end of the Cold War were ITS records opened to the public, with copies of the original documents made available to survivors and their families. The ITS changed its practices from using and considering ITS documents exclusively as a means to trace the fate and/or whereabouts of individuals persecuted and/or displaced by the crimes and aggression of the Nazi regime because of a growing understanding by the international community that these documents constituted an end in themselves. This change coincided with the International Commission for the ITS and its affiliated member state archives playing an increasingly pro-active supervisory role over the ITS. This, in turn, encouraged the ITS to conceive of and reconstitute itself as an archive, serving globally both victims and their descendants as well as scholars and journalists for historical research and documentation purposes.
\end{abstract}

\section{Introduction}

From my vantage point as the first director recruited and appointed by the International Commission for the International Tracing Service (ITS), I am struck by the apparent correlation between the number of international players involved in shaping the ITS, and the level of commitment to the mission of serving the breadth of victims of the Nazi regime, whether in terms of traditional tracing, fate clarification and documentation for restitution or memorialization. These international players include Allied agencies and their representatives, members of the International Commission for the ITS and the related archival partner institu-

Ә OpenAccess. ( 2020 Rebecca Boehling, published by De Gruyter. (cc) BY-NC-ND This work is licensed under the Creative Commons Attribution-NonCommercial-NoDerivatives 4.0 License. 
tions, as well as international staff working at the ITS, whether Displaced Persons (DPs) or their spouses, especially those representing supranational, even transnational interests. The more international the influence was on and within the ITS the more likely the ITS and its staff were to manifest and reflect a transnational culture of memory, one transcending nationalism and national identity, and to advocate for an increasingly broadly defined group of victims. An increase in transnational influences made the ITS more inclined to conceive of itself as serving historical research and documentation purposes. In contrast, national interests and national legislation based upon racial and cultural biases against Roma and Sinti, homosexuals, those deemed physically or mentally "abnormal" or non-conformist in their behavior, and political biases against communists and other leftists in the West worked against a widening of the understanding of which innocent people had been incarcerated, tortured, even killed or worked to death by the Nazis. ${ }^{1}$ An international declaration of human rights in 1948 may have purported to protect a panoply of rights for all, but not even all UN member states signed on and certainly the practices and legislation at home in many member states fell far short of the Universal Declaration of Human Rights. ${ }^{2}$ For much of its history the understanding of who had been victimized by the Nazis and who thus deserved recognition and compensation was culturally and politically and socially biased at the ITS, just as it was among many of its Allied founders.

\section{Early History of the ITS}

When the ITS began its work as the International Tracing Service in early 1948 its main task was tracing those civilians missing because of Nazi persecution and the war in Europe. The ITS was the successor to SHAEF's Tracing and Locating Unit as well as the Central Tracing Bureau, which was created first under the United Nations Relief and Rehabilitation Administration (UNRRA) and then, as of 1947, under UNRRA's successor, the International Refugee Organization (IRO). In the midst of conquering Germany and the liberation of surviving victims of Nazism, the Allies, in particular the British and Americans, collected docu-

1 In the Soviet bloc, the tendency was to focus on the victimization of communists while downplaying racial persecution, including the specific genocidal policies against Jews or Sinti and Roma, while playing down the persecution of Communists was the norm at the ITS under ICRC and western influence.

2 For the text and voting information on the Universal Declaration of Human Rights, see: https://www.ohchr.org/EN/UDHR/Pages/UDHRIndex.aspx. Last accessed: 30.3.2019. 
ments that survived the attempted destruction of records of concentration camps, prisons as well as of forced labor. These documents became part of the collection that moved to Arolsen, documents that could help trace the path of persecution both of victims who did and those who did not survive. The ITS, under the jurisdiction of the IRO, also documented the post-war whereabouts of survivors of Nazi persecution and those left displaced from their homelands, the so-called Displaced Persons (DPs), whose housing, care and maintenance as well as preparation for either repatriation or emigration the IRO managed. This in turn helped facilitate family reunification, a traditional goal of tracing organizations.

The Second World War Allies created the ITS to trace civilians from all the Allied countries, referred to at the time as the united nations, a term first coined by United States President Franklin D. Roosevelt in the Declaration by United Nations of January 1, 1942, when representatives of 26 nations pledged their governments to continue fighting together against the Axis Powers. This declaration predated the October 1945 founding of the United Nations organization, and included only those nations united in opposition to Germany and her allies. ${ }^{3}$ The identity of the ITS continues to this day to be shaped by the Second World War (WWII) Allies, although neither exclusively nor consistently over this entire time by the same Allies conceived of in 1942, as the "united nations".

In the transition from UNRRA to the IRO, the Soviets withdrew their direct participation in the IRO's tracing efforts and never agreed to share responsibility for DPs. The Soviets never acknowledged DPs as a phenomenon in the way the western Allies, especially the US and Britain construed and then organized them. In contrast to its role in UNRRA, the Soviet Union did not join or back the IRO. So by the time the ITS was officially created, the Soviet Union had disengaged from Allied post-war tracing tasks. It did not participate in providing support for DPs, criticizing those resisting repatriation to the Soviet Union, its newly acquired territories, and eastern European countries that increasingly were becoming Sovietized and thus part of the new Eastern bloc. This meant that the new "International" Tracing Service in Arolsen, as initially conceived, was not truly international; in practice it did not involve all the "united nations" of all the WWII Allies that had fought and defeated Nazi Germany. This would also come to mean that under this limited western Allied control, the ITS would not provide easy access to information to or about Eastern Europeans, beyond those individuals already in Western Europe as DPs. Nor did the files left behind

3 United Nations: “History of the United Nations”. Available at: https://www.un.org/en/sec tions/history/history-united-nations/index.html. Last accessed: 29.3.2019. 
in Nazi sites of persecution in Eastern Europe find their way into the ITS document collection. This also limited the ability of the ITS to provide information to Eastern Europeans or those whose persecution had taken place in sites of persecution in Nazi-occupied Eastern Europe, even when, or if, the ITS tried to do so.

Of course this is only part of the story. Britain and the US, the primary players in the IRO, also increasingly ignored Soviet requests for repatriation of their citizens. This was especially true for Soviet requests for repatriation of people from recently Soviet-annexed areas like the western Ukraine, because Britain and the US did not recognize the legitimacy of this Soviet acquisition. Under the cover of care and maintenance, the IRO, and thus indirectly as its record keeper, the ITS, sometimes even assisted in harboring Eastern Europeans as DPs who had displayed highly suspect collaborative behavior during the German occupation of the East and thus helped them emigrate to countries like the US or Britain, either because of their political, especially anti-Soviet or anti-communist, intelligence or military-related scientific expertise. This Cold War activity limited the potential of the ITS to develop a supra- or transnational identity, making it from the beginning a western institution, dedicated to serving the western Allied governments and select Allied victims of the Nazis. ${ }^{4}$

\section{Who Fell under the ITS Mandate? The Role of National Identity and the Cold War}

But how did the ITS define who counted as victims of the Nazis and thus fell under its mandate? As Henning Borggräfe and Hanne Leßau remind us, even in the early years of the ITS and its predecessor institutions, nationality took on more significance in the practice of responding to tracing and fate clarification inquiries rather than type of persecution or basis of victimhood. In fact the nationality of the sought-after person or the person doing the seeking could determine whether the inquiry fell under the ITS's tracing mandate or not. ${ }^{5}$ This,

\footnotetext{
4 For more on the ITS as a western pawn, specifically an extension of US foreign policy in the Cold War, see Jennifer L. Rodgers: "Archive of Horrors, Archive of Hope: The ITS in the Postwar Era”, in Elizabeth Anthony, Rebecca Boehling, Suzanne Brown-Fleming and Susanne Urban (eds.): Freilegungen: Spiegelungen der NS-Verfolgung und ihrer Konsequenzen, Göttingen: Wallstein, 2015, 17-34, here 25-26.

5 Henning Borggräfe and Hanne Leßau: "Die Wahrnehmung der NS-Verbrechen und der Umgang mit den NS-Verfolgten im International Tracing Service”, in Henning Borggräfe, Hanne Leßau and Harald Schmid (eds.): Fundstücke: Die Wahrnehmung der NS-Verbrechen und ihrer Opfer im Wandel, Göttingen: Wallstein, 23-44, here 25. See also in the same volume Henning
} 
however, was not simply due to one's geopolitical position within the Cold War division of Europe. Initially citizens of defeated Germany and of Nazi Germany's allied countries did not fall under the UNRRA or IRO tracing mandates and thus were not eligible to request information or assistance from the ITS. In fact, unless they were Jewish, Germans, regardless of their level of persecution, were rarely eligible to be regarded as DPs or to receive the care and maintenance that DP status carried with it.

As the need for both evidence for the prosecution of war crimes as well as the basis for restitution for victims or their heirs arose, these Nazi documents held at the ITS served a judicial purpose as well. They were requested for use by German and Allied courts and offices for prosecution purposes, while survivors and the families of victims, including those from Germany and those from Nazi-allied countries, also sought to provide proof of their persecution. As Jennifer Rodgers tells us, this proof was used for purposes of "certifying claims and issuing death certificates for social welfare and indemnification programs."6 This broadened the functions of the ITS records beyond tracing missing persons to tracing one's path of persecution and tracing the identities and behavior of perpetrators. Such uses, however, did not lead to a reconceptualization of the ITS as a research center, or even an archive. The character of the IRO, as the ITS was known in the region for years, and by some of the older generation in the area even today, was affected by the fact that UNRRA and its successor the IRO, as relief agencies, both served and employed Displaced Persons at the ITS. ${ }^{7}$ Those Displaced Persons, including some from eastern Europe who did not wish to be repatriated, also played a special role in providing first

Borggräfe: "Zum Geleit”, 7-8, and Harald Schmid: "Zwischen Achtung und Ächtung: Opfer nationalsozialistischer Herrschaft im Bild der deutschen Öffentlichkeit”, 10-22, here 17. They in fact show that it was not just nationality that determined whether one was deemed a victim worthy of ITS assistance. The ITS staff were affected by their surrounding culture's understanding of who had been victimized by the Nazis for Nazi-defined reasons, as opposed to for allegedly criminal and therefore not specifically Nazi, or even 'unwarranted' reasons, thus justifying the incarceration or even the resulting death. The authors argue that ironically even when West German society, at least its historians and intellectuals, came to realize that victims of the Nazis included those the Nazi records labeled "asocials", "criminal" elements, homosexuals, those involuntarily sterilized, so-called Gypsies, forced laborers and not just political and racial victims, the ITS staff under ICRC leadership continued to use the 1950s' restrictive definitions of who constituted legitimate victims of the Nazis, and who thus were worthy of compensation.

6 Jennifer L. Rodgers: “'Humanity's Ancestral Inheritance': The International Tracing Service, 1942-2008”, Arolsen Archives website, see https://arolsen-archives.org/content/uploads/hu manitys-ancestral-inheritance-rodgers.pdf. Last accessed: 2.9.2019.

7 Rodgers: “Archive of Horrors, Archive of Hope”, 28. 
hand-knowledge of forced labor and/or incarceration along their own paths of persecution and displacement. Such DPs were predisposed to a commitment to preserving the historical record of persecution alongside the information needed for tracing missing persons and reuniting families, which however does not mean they were immune to ethnic and nationalist biases, or antisemitism, for that matter. But like many DPs not wishing to return to their homelands, many former Nazi victims working at the early ITS were inclined to distance themselves from strong nationalism and national allegiances. But although more inclined toward what we would now call transnationalism, such DPs were of course also likely to share the anti-communism of their homelands as well as that of the Western Allies, which was becoming ever more overt. ${ }^{8}$ This was especially true during the tensions of the Cold War in Europe from 1948 onward, and particularly as of 1951 as the (western) Allied High Commission for Germany (HICOG) took over responsibility from the IRO for administering the ITS, with the United States taking on the leadership role. ${ }^{9}$

It is significant that the international staff of the early ITS, well into the 1950s, identified with at least some of the people whose records they oversaw and for whom they did tracing and documentation work. They were contemporaries and in some cases they shared similar fates, or they identified with the Allied soldiers, seen as liberators, who had defeated those Germans they considered perpetrators. A number of Allied civilians also worked alongside the DPs at the early ITS. Most were less likely to identify with the local Germans, although they surely came into contact with them in their daily lives, but not so often in their ITS workplace. It was several years after the founding of the ITS before significant numbers of local Germans worked in regular staff positions

8 Anna Holian: Between National Socialism and Soviet Communism: Displaced Persons in Postwar Germany, Ann Arbor/Michigan: University of Michigan Press, 2011, 119; Diane Afoumado: "The 'Care and Maintenance in Germany' Collection - A Reflection of DP Self-Identification and Postwar Emigration”, in René Bienert, Rebecca Boehling and Susanne Urban (eds.): Freilegungen: Displaced Persons. Leben im Transit: Überlebende zwischen Repatriierung, Rehabilitation und Neuanfang, Göttingen: Wallstein, 2014, 217-227, here 225. See also Laura J. Hilton: "The Experiences and Impact of the Stateless in the Postwar Period”, 156-172, here especially 167. Also in the same volume, see Ruth Balint: "The Use and Abuse of History: Displaced Persons in the ITS Digital Archive”, 173-186.

9 Charles Elbot, son of Hugh, G. Elbot, head of the Executive Board of the ITS during the HICOG period, described his father as "a Cold War warrior". In explaining his father's commitment to working at the ITS, Charles also stressed Hugh's concern for the survivors and victims of the Nazis. Telephone conversation with the author, 21.7.2019. 
at the ITS. ${ }^{10}$ This seems to correlate with both the age- and presumably healthrelated retirements of DPs as well as the 1951 to 1955 control of the ITS by the Allied High Commission for Germany, and then the 1955 takeover of the administration of the ITS, at the request of the western Allies, by the International Committee of the Red Cross.

\section{The Hegemonic Role of the United States}

The Americans, who led the ITS under its HICOG control phase from 1951 to 1955, oversaw a period of ever-decreasing transnational influence in and on the ITS. Jennifer Rodgers argues that the ITS, especially in the 1950s, gave inquiries from US agencies precedence over other requests. ${ }^{11}$ This would not be surprising given the location of the ITS in the US zone of occupied Germany, the fact that the US provided the single highest contribution to the funding of the IRO and held the largest number of officers in the IRO Secretariat, ${ }^{12}$ and that the ITS was led from 1951 to 1955 by an American. All of the DP camps directly run by the IRO were in the US zone of occupied Germany, while the IRO had a more limited oversight role over those in the British occupation zone. All of this points to the hegemonic role of the US within the IRO, even before the HICOG phase. During the HICOG phase itself, the US chaired the tripartite Executive Board of the ITS, which represented the three Western Allies, the British, French and Americans. It is not surprising during both the IRO and the HICOG phases that the ITS would have shown precedence to US agency requests.

It should be noted that soon after the American head of the HICOG tripartite Executive Board of the ITS, Hugh G. Elbot, took over his supervisory position at the ITS in 1951, he felt compelled to report to his superiors in Frankfurt that “about 45 top Nazis (including SS leaders, Gestapomen [sic] and Golden badge-party members) and about 5 Communists were recently removed, after having been employed under IRO supervision for several years." He noted the

10 This information derives from conversations I had while director of the ITS from 2013 to 2015 with older and recently retired ITS staff as well as with older Arolsen locals as well as from photographs and signatures on early documents from the ITS. A detailed analysis of personnel records would be necessary to confirm the exact nationalities of the staff at any given point, especially prior to 1955 .

11 Rodgers: “Archive of Horrors, Archive of Hope”, 25.

12 "International Refugee Organization", in Yearbook of the United Nations, 1951, 990-991. Available at: https://read.un-ilibrary.org/united-nations/yearbook-of-the-united-nations-1950_ 418b1872-en\#page8-9. Last accessed: 20.3.2019. 
strong opposition of the German manager and other Germans to the removal of "those elements." ${ }^{13}$ Elbot, a German-speaking Jewish refugee from Czechoslovakia, who fled Central Europe in 1938 and joined the US military during the war, had misgivings about German influence at the ITS, but such misgivings were not typical, however, of his superiors in HICOG or the State Department. ${ }^{14}$

Following the 1954 repeal of the Occupation Statute in Germany, an International Commission (IC) of nine member states (Belgium, the Federal Republic of Germany, France, Israel, Italy, Luxembourg, the Netherlands, the United Kingdom, and the United States) was formed to charge the ITS with continuing its tracing services while protecting and utilizing the documents in Arolsen. During the HICOG phase the US government had hoped it would not be long before it could turn over the ITS to German control. But several of Germany's former WWII foes and, not unexpectedly, Israel, resisted this idea. Some Western Allies, including countries with sizable numbers of Nazi victims, were wary of Germans having control over the ITS, yet did want West Germany to pay for its staff and operations. Even the US representative on the Executive Board overseeing the ITS during the HICOG phase, Hugh G. Elbot, argued against his employer, the State Department, in advocating against turning over the ITS to the Germans "for the sake of posterity" and in order to safeguard the records and their accessibility. ${ }^{15}$

The government of the young Federal Republic was disappointed that an International Commission was formed to oversee the ITS. The Federal Republic did agree to shoulder the expense of funding the ITS, its operations and staff, partly to diffuse international tensions over the issue of potential German control over the ITS. ${ }^{16}$ The ITS's reliance on German funding did of course spell greater German influence and a steady increase in the number of German staff working at the ITS. Germany was anxious to dispel distrust among its new-found Cold War

13 Hugh G. Elbot to G. J. Swope, Memo on "Future of the ITS", 6. 2.1952, 2, 6.1.1/82507305/ITS Digital Archive, USHMM.

14 Charles Elbot (son of Hugh G. Elbot), telephone conversation with the author, 21.7.2019. 15 Charles Elbot, telephone conversation with the author, 21.7.2019. Although the US representative to HICOG's tripartite Executive Board overseeing the ITS, Hugh G. Elbot, wanted the ITS to remain under international control and not come under German control, the US State Department under John Foster Dulles advocated turning the ITS over to the Germans. According to Charles Elbot, Hugh G. Elbot's son, his father's persistent opposition to turning over the ITS to Germany, as expressed to his superior Dulles, helped prevent this from happening. See also Hugh G. Elbot to G. J. Swope, "Future of the ITS", 6.2.1952, in which Elbot argued that the "Germans, if left alone, would tend to reemploy unreliable elements." 6.1.1/82507305/ITS Digital Archive, USHMM.

16 Rodgers: "Archive of Horrors, Archive of Hope", 27. 
allies in the midst of achieving stronger western integration and full sovereignty. The first major West German law to indemnify victims of the Nazi regime went into effect in 1953 (Bundesentschädigungsgesetz or BEG), providing compensation to both non-German and German victims, at least as defined at the time. But victims had to provide proof of internment, and it quickly became clear that the Nazi concentration camp and prison records held at the ITS were critical evidence. ${ }^{17}$ Alongside its various "Wiedergutmachung" programs to show it was rehabilitating itself, the Federal Republic had come to realize it might save money by using ITS documents to certify claims of persecution and death rather than risk facing redundant claims. ${ }^{18}$

In the Bonn Accords of 1955, the International Commission had oversight authority over the ITS, yet did not want to manage it directly. The IC sought an institution that would be seen as neutral and apolitical, at least as defined within the constraints of the anti-communist, anti-Soviet West in the midst of the 1950s Cold War. Because the Red Cross, with its various national branches, in particular the British Red Cross, had been involved in the early tracing tasks taken on by the ITS and its predecessor organizations, the decision was made to ask the International Committee of the Red Cross (ICRC) to provide the administrative structure under which the ITS was to function: a Swiss delegate of the ICRC, accountable both to the ICRC and the International Commission, was to oversee the ITS's day-to-day operations while reporting to the Commission at its annual meetings. ${ }^{19}$ Under ICRC management and with the approval of the IC, the ITS staff acted primarily as a tracing service for victims of Nazi crimes, providing documentation on victims' paths of persecution and fates, while, like other tracing services, helping to reunite families. Occasionally it would also provide documentation on perpetrators to judicial authorities. Civilian victims and their descendants had the right to request information from the ITS pertaining to their individual cases, but they were not granted direct access to the documents. ${ }^{20}$

17 Jean-Marc Dreyfus: “Opening the Nazi Archives at Bad Arolsen”, Books\&ideas.net, 11.4.2013, 3-4. Available at: https://booksandideas.net/IMG/pdf/20130411_dreyfus_arolsen_en.pdf. Last accessed 29.3.2019. Original French version first published by Laviedesidees.fr, 11.9. 2008. Translated by Eric Rosencrantz.

18 Rodgers: "Archive of Horrors, Archive of Hope", 26-27.

19 As an ICRC delegate, the ITS director was paid directly by the ICRC and had diplomatic immunity in Germany.

20 Paul Belkin: "Opening of the International Tracing Service's Holocaust Era Archives in Bad Arolsen, Germany”, Congressional Research Service Report for (US) Congress, 11.12.2007. Available at: https://www.everycrsreport.com/reports/RS22638.html. Last accessed: 18.2.2019. 


\section{The Role of Swiss Management: The International Committee of the Red Cross (ICRC)}

Switzerland had been one of the 20 member states of the IRO, the headquarters of which were in Geneva, Switzerland, yet Switzerland had not fought against the Axis Powers, and thus was not an IC member. Instead the Swiss-run ICRC, also headquartered in Geneva, provided the director of the ITS, who formally reported both to the ICRC and to the International Commission. The Western Allied governments considered the ICRC, with its Swiss origins and headquarters, as both neutral and apolitical. By agreeing to administer the ITS, the ICRC had hopes of compensating for its less than stellar moral role on behalf of Nazi victims during the war. One might have thought that ICRC management would have made the ITS more transnational, or supranational during its administrative management of the ITS from 1955 until 2012, especially as compared to the HICOG phase. Instead the ICRC continued the HICOG policy of rejecting inquiries from the Eastern bloc, arguing that such requests were of a political nature, while claiming that the ITS under the ICRC was focused on "humanitarian" requests. ${ }^{21}$

In hiring more Germans from the area around Arolsen to replace the previously more international and more formally educated staff, the ITS under the ICRC took on a more provincial tone. ${ }^{22}$ Its German staff had minimal direct experience with victims of Nazism and were less well-versed in the historical or geographical context of Nazi persecution and atrocities across Europe. The requests for information that the ITS staff provided were based on documents indexed solely by names, documents primarily authored by Nazi officials. Under ICRC management, fewer and fewer of the staff were equipped to interpret the information they were providing to victims and their descendants. ${ }^{23}$ Had the ITS

21 Rodgers: "Archive of Horrors, Archive of Hope", 27.

22 There are no universities in the vicinity of Arolsen, with the closest a hundred kilometers away in Göttingen in what had been the Kingdom of Hanover, and later became Lower Saxony, but at the end of the war was in the British zone of occupation, unlike Arolsen in the state of Hesse in the US zone. Such boundaries made it very unlikely that those in the Arolsen area would have ever pursued studies at the University of Göttingen. The University of Kassel, some $50 \mathrm{~km}$ away from Arolsen, was not founded until the 1970s.

23 During my ITS directorship veteran staff confided in me how under ICRC management they had rarely been encouraged to do research themselves or to consult with each other about ways to piece together or interpret information. There was allegedly an unwritten policy under the long-time (1985 - 2006) ICRC director, Charles-Claude Biedermann, not to hire college graduates or anyone with a German Abitur (advanced pre-university high school degree). Biedermann pro- 
under the ICRC decided to open the ITS for research, few on the staff would have been able to help facilitate it. On the other hand, the staff would have benefitted from the knowledge of researchers and made better use of the early historical information and analysis that had been prepared explicitly by an international historical division in the early years of the ITS, but which they were rarely encouraged to use. According to Susanne Urban, director of the ITS Research and Education Department from 2009 until 2015, these historical materials, including the approximately 1100 completed Death March and Concentration Camp Questionnaires that were sent out in 1950 to generate and revise a Catalogue of Camps and Prisons were used less and less by the ITS staff to answer inquiries or provide information to authorities after 1951. Instead they were stored in a basement in one of the ITS buildings until 2009, after the ITS had officially opened for research two years before. ${ }^{24}$

There is evidence that the ITS intermittently did provide replies to historical inquiries from the mid-1950s until the mid-1970s. In fact, while under the direction of Albert de Cocatrix from 1970 to 1977, the ITS became actively engaged in corresponding with and receiving visitors, including scholars. This policy changed with his departure, resulting in an overall decline in inquiries under his successor, Philipp Züger. Then in 1985, under the leadership of CharlesClaude Biedermann, who remained director for over 20 years, access to ITS files and many of its facilities became off-limits without the director's explicit authorization. ${ }^{25}$ The decade prior to the reunification of Germany, while first Züger and then Biedermann were the ITS directors, coincided with a wave of popular and scholarly interest in National Socialism and the Third Reich in West Germany and WWII globally. The number of survivors of Nazi persecution was of course steadily declining, but a younger generation of historians and descendants of survivors began asking more questions. While Biedermann was director of the ITS, the number of inquiries skyrocketed, as did the backlog and wait time for those hoping for answers. With the collapse of the Soviet Union the ITS was able to acquire copies of new records held in the former Eastern bloc, which increased the volume of requests and raised expectations about speedy replies and

moted a very secretive and closed environment at the ITS, allegedly banning staff from talking about their work, not only outside work but also generally with each other while at work. 24 Susanne Urban: "'Mein einziger Dokument ist der Nummer auf der Hand'. Schriftliche Aussagen Überlebender im Archiv des ITS”, in René Bienert, Rebecca Boehling and Susanne Urban (eds.): Freilegungen: Überlebende - Erinnerungen - Transformationen, Göttingen: Wallstein, 2013, 173-197, here 188-190.

25 Dreyfus: "Opening the Nazi Archives at Bad Arolsen”, 5-6. 
scholarly access. The compensation claims of former forced laborers from Eastern Europe also placed Arolsen's records in demand. ${ }^{26}$

\section{The ITS as an Archive for Research?}

Although the ITS records were increasingly utilized from the 1950s onward for judicial and restitution proceedings as well as to document victims' paths of persecution and occasionally still to reunite families, within the ITS and among its ICRC leadership, the ITS continued to be understood primarily under its initial mandate and name, as a tracing service. Except during this brief period in the 1970s under Albert de Cocatrix, its potential for research was stifled; its identity as an archive, a treasure trove of historical documents, suppressed. Even as survivors and family members of victims sent in documentation in the so-called correspondence or T/D files that supplemented the materials the ITS initially had from former concentration camps and prisons and that it became the repository for, there was little sense of the ITS constituting an archive. This was true even as the ITS actively sought and gathered documents and copies of documents from archives to supplement its collections. ${ }^{27}$

The decision in the 1990s to digitize the documents was less a reflection of this attitude changing, or of the recognition for the need for preservation, than of the need to speed up the process of searching within the documents, without staff having to move the original documents constantly from place to place, risking misfiling and loss. Yet in many ways this mass digitization process made it ever more clear, to outsiders, if not insiders, that the ITS had become an important repository of records for the history of the victims of the Nazi regime as well as for the criminal behavior and bureaucratic nature of the Nazi regime as it gathered and tortured and killed those it perceived as enemies.

During much of this more than a half century of ICRC management the documents of the ITS remained closed both to the public and to scholars - a policy that by the 1990s provoked increasingly strong criticism of the institution, from the international scholarly community as well as from the IC. In the IC more archivists and historians of the Holocaust and Nazi Germany came to take seats alongside the diplomats, without voting rights, of course, to represent the inter-

26 Ibid., 6-7.

27 Jan Erik Schulte: "Nationalsozialismus und europäische Migrationsgeschichte: Das Archiv des Internationalen Suchdienstes in Arolsen”, in Zeithistorische Forschungen/ Studies in Contemporary History, 4, 2007, 223-232, here 225. 
ests of the historical record as well as the legacy of those countrymen and countrywomen who had suffered at the hands of the Nazis and their allies.

The May 2006 decision of the International Commission to open up the ITS for historical research, concomitant with the recall of Biedermann, marked not only a remarkable change in accessibility but a new understanding of the ITS as an archive. Yet this did not come overnight. In 1995 the IC had voted to open up the ITS records to research, but the leadership of the ITS, citing concerns with the fact that ITS records referred to individuals and citing various data privacy laws in Germany and other parts of Europe that restricted access to personal data, had managed to fend off the opening, except to those general historical documents not pertaining to individuals. ${ }^{28}$ More than a decade passed with increasing rumors of scandals related to Biedermann and practices within the ITS alongside pressure from scholars and the media before the IC was able to prevail.

Interestingly enough for me, as the first post-ICRC director of the ITS, few of the histories of the ITS focus much attention on the International Commission. The assumption is that the ICRC was able to act autonomously, at least within the constraints of German financial accountability and labor law, under which all the employees fell, except the ICRC staff, who were on temporary assignment in Arolsen. Until a detailed study of the ICRC and its relations with the International Commission is undertaken, we will not know in any detail how much autonomy the ICRC had and how and at which junctures the IC pulled in the reins. We do know that when revelations reached the public about the abuse of power of the ICRC Director Biedermann and the arbitrary practices of granting select people access to the archives, while resisting granting access even to members of the International Commission, that calculated pressure led to Biedermann's departure and the opening of the archives in late 2007. CBS's 60 Minutes highlighted the significance of this opening, thanks especially to Paul Shapiro and the United States Holocaust Memorial Museum, with its unfortunately ill-named investigative report entitled Hitler's Secret Archive, which aired in December 2006.

I would suggest that it was really only at this point, with digitization underway already several years, that internally the ICRC and some of the staff had begun to think of the ITS as an archive. The opening of the archive of the ITS to the public may have transformed the external perception of the identity of the ITS as an archive that had long served the purposes of a tracing service to that of an archival repository for historical research, in particular for researchers and journalists anxious to delve into the records. Of course once researchers en-

28 Ibid., 225. 
countered the pitfalls of the OuS (Ossenberg und Schneider) software system used to classify the digitized documents primarily for name research their initial enthusiasm was somewhat dampened.

The core Inquiry (once called the Humanitarian Branch) and Tracing staff, with their lack of familiarity with other archives, typically thought of the documents in the ITS as a means to the end of answering survivor and family requests for information about victims or DPs. Yet once the ITS was open to the public, survivors and relatives of victims from across the world came personally to the ITS to see the relevant documents, and eventually once the ICRC no longer managed the ITS, to get copies of them and to meet with the staff to get (and to provide) more context to understand what the documents meant. This began to transform the significance of the documents for the Inquiry staff, at least those who met with or talked to or corresponded with inquirers. The documents and the archive as a whole started to constitute what child survivor and former International Criminal Court judge and ITS visitor Thomas Buergenthal called "sacred ground."29 Once the Research and Education Department was created and the Archives Department was more fully developed a growing segment of the ITS staff came to think of the records in the archives as not just a means but an end in themselves. The Archives Department oriented itself to facilitating research by the public, whether scholars or journalists or pupils. Yet the ITS, and in particular its German government funders, still needed to be sure that the staff of what was once called the Humanitarian Branch and the ever-smaller Tracing Service Division with its ties to other Red Cross and Red Crescent and Magen David Adom tracing services across the world, would be able to find the documents they needed to focus on answering the 1,000 plus per month survivor and family inquiries about individuals (name searches).

\section{Conclusion}

So what are the implications of the changing practices of the ITS and its managers and staff, from using and considering ITS documents as a means to trace the fate and/or whereabouts of individuals persecuted and/or displaced by the crimes and aggression of the Nazi regime, on the one hand, to the growing understanding of these documents as an end in themselves by the International Commission for the ITS and its affiliated member state archives as well as by re-

29 Thomas Buergenthal used this terminology in his keynote address on the occasion of the ICRC departure ceremony on November 29, 2012 in Bad Arolsen. 
cently hired academics on the ITS staff? I would argue that there is a danger of the ITS becoming seen as "just an archive," downplaying its relevance as both "sacred ground" for survivors, victims and their descendants, particularly as younger researchers and officials grow accustomed to conducting digital searches and never seeing or appreciating actual paper archives or valuing the documents in and of themselves, with their original signatures and handwritten details. Even the Federal Republic of Germany, the host country and International Commission member and the ITS's sole official funder, has not always understood the value of these "papers" in and of themselves, as evidenced by the manner in which they were long maintained and stored.

The misunderstanding that digitization of the documents could render unnecessary the preservation of the original documents has been countered by the growing role of archivists and historians both within the ITS and the International Commission, including of course the institutional partner, the German Federal Archives, and the ITS's affiliated member state archives. The reaction of $\mathrm{Be}$ troffene, such as Thomas Buergenthal, and their relatives when they come to Bad Arolsen to see the actual documents, not only pertaining to, but sometimes written or at least signed by, their loved ones has enhanced the value of the documents. This is of course evidenced by the entry of the ITS archive into UNESCO's Memory of the World and the official recognition by the IC and the German funding host, of the necessity of a climate-controlled archival facility for the records of the ITS. The International Commission, which in the last decade and a half has played such a key role in assuring that the ITS archives is appropriately preserved and maintained and made accessible to the public, will likely receive a much more prominent place in the history of the ITS, as should the ITS staff, who despite their administrative challenges and obstacles, have worked to fulfill the mission of the ITS, in all its changing dimensions. 
